\title{
MOLLUSCAN DIVERSIFICATION AND EXTINCTION ON OPPOSITE SIDES OF THE ISTHMUS OF PANAMA
}

JACKSON*, Jeremy B. C., Center for Paleoecology, Smithsonian Tropical Research Institute, Box 2072 Balboa, Republic of Panama; JUNG, Peter, Naturhistorisches Museum, Augustinergasse 2, CH-4001, Basel, Switzerland

Molluscs are the most diverse and abundant tropical American macrofossils, but their distributions and evolution are not well understood. Classic studies by Olsson and Woodring documented a rich Late Miocene to Early Pliocene "Gatunian" fauna throughout the Caribbean and tropical Eastern Pacific, with many species in common between the oceans. This fauna was divided by formation of the Isthmus of Panama, and diverged into distinct Pacific and Caribbean faunas sometime thereafter. Diversity also decreased by about half in the Caribbean. However, the timing, rates and correlation of these major biological changes with changes in environmental conditions have not been resolved because of imprecise dating and taxonomy and failure to consider problems of sampling and biofacies in biological comparisons. We used the newly revised late Neogene stratigraphy for Panama and Costa Rica to date for the first time the radiation and extinction of molluscs on opposite sides of the Isthmus. Data include occurrences throughout tropical America for nearly 100 species of the Strombina-group (Gastropoda, Columbellidae) and for more than 500 gastropod and bivalve genera from 240 Late Miocene to Pleistocene isthmian collections.

All evidence suggests that final closure of the Isthmus of Panama occurred between 3.5 and $2.5 \mathrm{My}$. Subgeneric divergence between the oceans was well developed, and trans-isthmian species were rare by the Early Pliocene, at least $2 \mathrm{Ma}$ before final closure. Caribbean diversity remained high until 1.8 to 1.5 Ma when massive but selective extinction occurred. This was at least $1 \mathrm{Ma}$ after final closure of the Isthmus, and may be correlated with onset of slightly cooler Caribbean sea surface temperatures in the Pleistocene. In contrast, Eastern Pacific diversity did not decline, and even increased during the Pleistocene. 